\title{
Persepsi dan Kesiapan Mengajar Mahasiswa Guru Terhadap Anak Berkebutuhan Khusus dalam Konteks Sekolah Inklusi
}

\author{
M. Kusuma Wardhani \\ kusuma.wardhani@uph.edu \\ FIP Universitas Pelita Harapan \\ Pre-Service Teacher's Perception and Readiness for Teaching Students
with Special Needs in The Context of Inclusive School
}

\begin{abstract}
The implementation of inclusive education in reality, really requires readiness and support from various parties, including fron the educators who are ready in the sense of being able and willing to educate children with special needs. The focus of this study is to examine the perceptions of pre-service teachers in Pelita Harapan University for children with special needs who have access to inclusive education, and what factors underlie these perceptions. The next focus is whether the pre-service teachers have the readiness or vice versa just that there is still doubt or reluctance to teach in inclusive schools. The research method is qualitative descriptive. The number of respondents was one class consisting of 40 students which was a combination of 2 two study programs. The results showed that pre service teachers had perceptions that children with special needs could attend school in inclusive schools, and will be successfull. The arguments that underlie these perceptions are three things: the equal right to education for everyone; curriculumadjustment, teaching methods, assessments and facilities for students with special needs; inclusive schools are a combination of public schools with special schools, and adjustments for each child with special needs in the form of PPI (Individual Development Program). All respondents stated their readiness to teach in inclusive schools._The reason are because a teacher should treat his student equally, the subject of Teaching Student With Special Ability courses has equipped them, and adjustments made in inclusive schools in terms of methods, curriculum, assessment and infrastructure.
\end{abstract}

Keywords: Children with Special Needs, Inclusive Education, Perception, Readiness

Received date: 18 Maret 2020

\section{Article Info}

Revised date: 14 Mei 2020

Accepted date: 14 Mei 2020

\section{PENDAHULUAN}

Belajar adalah suatu proses dan aktivitas yang dikerjakan oleh semua manusia, sejak ia berada dalam kandungan, lahir, tumbuh menjadi kanak-kanak, remaja dan akhirnya menjadi orang dewasa, sesuai dengan prinsip pembelajaran sepanjang hayat. Knigt (2009: 10) dalam bukunya filsafat dan Pendidikan menyatakan bahwa Pendidikan dapat dilihat sebagai sub bagian dari belajar. Pendidikan adalah suatu kesengajaan yang dilakukan oleh pembelajar untuk mengarahkan suatu situasi belajar dengan maksud memperoleh tujuan belajar yang diinginkan (goal). Hakekat pendidikan adalah memanusiakan manusia, mengembangkan potensi dasar setiap individu, agar cakap dan percaya diri dalam menghadapi masalah masalah kehidupan yang dihadapi tanpa merasa tertekan, dan melakukannya dengan senang. Saleh dan Filawati (2019: 76) menegaskan bahwa untuk menciptakan masyarakat yang unggul dan berdaya saing, maka pendidikan adalah hal yang sangat penting untuk mengembangkan sumber daya manusia.

Dengan melihat definisi di atas, maka sudah selayaknya bahwa pendidikan adalah hak setiap orang, tanpa memandang keberadaannya. Tetapi yang menjadi permasalahan adalah setiap orang dilahirkan tidak ada yang sama, semua mempunyai keunikan masing-masing, dengan demikian mempunyai kebutuhan dan kemampuan yang berbeda beda pula dalam mengikuti Pendidikan ,

Undang Undang Dasar tahun 1945, memberikan jaminan hak kepada setiap warga negara untuk mendapatkan pendidikan, dan setiap warga negara wajib melaksanakan pendidikan dasar. Dalam hal 
ini termasuk pula anak anak yang berkebutuhan khusus, dijamin oleh negara untuk mendapatkan akses Pendidikan sesuai kebutuhan mereka.

Hal ini sejalan dengan ideologi pendidikan inklusif yang diperkenalkan secara internasional dalam Konferensi Dunia tahun 1994 di Salamanca Spanyol oleh UNESCO. Pernyataannya menyerukan tentang komitmen terhadap pendidikan untuk anak, remaja dan orang dewasa yang memerlukan pendidikan di dalam sistem Pendidikan regular, dan menyetujui suatu kerangka aksi mengenai pendidikan kebutuhan khusus, yang semangat dan ketetapan ketetapan serta rekomendasirekomendasinya diharapkan akan dijadikan pedoman oleh pemerintah pemerintah serta organisasi organisasi dalam menjamin hak setiap orang untuk mendapatkan Pendidikan yang berkualitas demi kehidupan yang bermartabat (Sugiarmin, 2003: 1-13)

Lebih lanjut Sugiarmin menyatakan bahwa, Pemerintah Indonesia sejak melaksanakan wajib belajar 9 tahun pada tahun 1994, telah memikirkan bahwa perlu adanya perubahan sudut pandang dalam penempatan peserta didik. Perspektif yang eksklusif dan segregatif tidak tepat lagi untuk dilaksanakan, karena itu artinya hanya memperhatikan hak kaum mayoritas, dalam hal ini adalah peserta didik regular, sedangkan kelompok peserta didik yang berbeda dalam hal ini anak yang mempunyai kebutuhan khusus, tidak mendapatkan tempat dalam skema ini. Pendapat ini sejalan dengan (Murniarti \& Anastasia, 2016: 9-18), memperoleh pendidikan adalah hak seluruh warga negara, termasuk anak berkebutuhan khusus.

Merujuk dari hal tersebut, UU Sisdiknas no 20 th 2003 tentang Sistem Pendidikan Nasional pasal 32 telah mengatur Pendidikan khusus dan Pendidikan layanan khusus, yang mana penjabarannya diturunkan dengan Permendiknas no 70 th 2009, yaitu memberikan peluang bagi anak berkebutuhan khusus mendapatkan pendidikan di sekolah regular (SD, SMP, SMA) yang lokasinya paling dekat dengan tempat tinggal anak anak tersebut. Definisi inilah yang dinamakan pendidikan inklusif .

Pengejawantahan dari rancangan pendidikan yang menggabungkan anak anak berkebutuhan khusus dengan anak anak normal dapat belajar bersama dalam lingkungan yang sama, adalah perwujudan dari Pendidikan inklusif (Murniarti \& Anastasia, 2016: 9-18).

Namun pelaksanaan Pendidikan inklusi pada kenyataannya, sangat membutuhkan kesiapan dan dukungan dari berbagai pihak, seperti tenaga pendidik, metode belajar, sistem evaluasi, pengeloaan pembelajaran, sarana prasarana, dan lain sebagainya. Menurut Mudjito (2012) masih banyak anak berkebutuhan khusus di Indonesia belum mendapatkan hak nya untuk meng-akses Pendidikan sesuai kebutuhannya. Berpedoman pada informasi dari Direktorat Pembinaan Khusus dan Layanan Khusus Pendidikan Dasar (2010), faktor utama yang menyebabkan rendahnya layanan ini antara lain adalah kurangnya tenaga pendidik yang siap dalam arti mampu dan mau mendidik anak berkebutuhan khusus. Artinya disini tidak hanya dibutuhkan guru yang secara kognitif dan skill berkompeten untuk mendidik anak berkebutuhan khusus, namun juga mempunyai hati yang mau melayani untuk mendidik anak berkebutuhan khusus. Hambatan untuk melaksanakan pendidikan inklusif selain kurikulum yang tidak mengakomodasi anak berkebutuhan khusus, asesmen yang tidak sesuai, juga faktor guru yang tidak mendukung (Amka,2019: 93). Penelitian dari Anggriana \& Trisnani, (2016: 159) menegaskan bahwa pelaksanaan Pendidikan inklusif belum didukung oleh guru guru yang mempunyai skill mengajar siswa difabel. Faktor yang lainnya adalah sekolah yang belum siap untuk memberikan pelayanan baik sarana maupun prasarana untuk aksesibilitas anak berkebutuhan khusus (Mumpuniarti \& Lestari, 2016 : 5761)

Berdasarkan fenomena di atas, fokus penelitian ini adalah mengkaji persepsi mahasiswa calon guru UPH kepada anak berkebutuhan khusus yang mendapatkan akses ke pendidikan inklusi, serta faktor apakah yang mendasari persepsi tersebut. Fokus selanjutnya adalah apakah para calon guru ini mempunyai kesiapan atau sebaliknya justrus masih ada keraguan atau keengganan untuk mengajar di sekolah inklusi. Hal ini akan menjadi jawaban bagi salah satu permasalahan pendidikan inklusi, yaitu kurangnya tenaga pendidik yang siap untuk mengajar anak anak berkebutuhan khusus yang disebabkan oleh kurangnya kompetensi guru dalam menangani anak berkebutuhan khusus. (Tarnoto, 2016:55). Penelitian serupa pernah dilakukan oleh beberapa penulis, berikut adalah judul, hasil penelitian, serta perbedaan nya dengan penelitian penulis. Penelitian dengan judul Sikap Mahasiswa Terhadap Pelaksanaan Pendidikan Inklusi (Hasnul, 2011: 150-162), dengan hasil sikap dan perilaku positif mahasiswa terhadap pendidikan. Penelitian yang dilakukan Hasnul melihat sikap mahasiswa, sedangkan peneliti memotret persepsi mahasiswa, sebelum mahasiswa menentukan sikapnya terhadap anak berkebutuhan khusus, apakah mereka siap mengajar anak-anak ini di sekolah inklusi. Selanjutnya 
adalah penelitian dari (Kurniadi \& Sunaryo, 2017: 22-28), berjudul Kesiapan Mahasiswa Calon Guru Sekolah Dasar Dalam Melayani Anak Berkebutuhan Khusus, dengan hasil belum terlihatnya kesiapan mahasiswa calon guru SD dalam melayani anak berkebutuhan khusus. Perbedaan dengan penellitian ini adalah, peneliti mendeskripsikan persepsi mahasiswa calon guru terlebih dahulu, melihat apa yang mendasari persepsinya, baru kemudian para responden tersebut menjelaskan kesiapan atau ketidak siapannya untuk mengajar di sekolah inklusi. Metode yang dipakai peneliti adalah kualitatif deskriptif, sedangkan Kurniadi dan Sunaryo menggunakan kuantitatif deskriptif.

\section{KAJIAN PUSTAKA}

Dalam KBBI, berkebutuhan khusus atau berkelainan artinya adalah mempunyai kelainan atau cacat. Pengertian anak berkelainan atau anak luar biasa adalah anak yang mempunyai kelainan atau penyimpangan dari rata rata anak anak normal, dalam aspek fisik, sosial dan mental, sehingga dalam pengembangan potensinya perlu layanan Pendidikan khusus sesuai dengan karakteristiknya (Effendi, 2006:26). Senada dengan itu Cahya (2017: 5) memaparkan bahwa anak berkebutuhan khusus adalah anak yang dalam pendidikan memerlukan pelayanan yang spesifik, berbeda ada anak pada umumnya. Anak- anak spesial ini mengalami hambatan dalam belajar dan perkembangannya atau dengan kata lain anak dengan problema belajar. Dengan demikian akan menjadi lebih jelas dalam Smith (2006 : 45) inklusi berarti bahwa tujuan pendidikan bagi siswa yang memiliki hambatan adalah, keterlibatan yang sebenarnya dari tiap anak dalam kehidupan sekolah yang menyeluruh. Penerimaan kepada anak anak yang memiliki hambatan ke dalam kurikulum, lingkungan, interaksi sosial dan konsep diri.

Chamidah (2014: 115-127) memaparkan klasifikasi anak berkebutuhan khusus, yang meliputi anak dengan gangguan penglihatan (tunanetra), anak dengan kelainan kecerdasan dibagi dua yaitu gangguan kecerdasan (tuna grahita) dan anak dengan kemampuna intelegensia di atas rata-rata (gifted), anak dengan gangguan anggota gerak (tunadaksa), anak dengan gangguan emosi dan perilaku (tuna laras), anak dengan dengan gangguan belajar spesifif yang terdiri atas anak lamban belajar, autis dan ADHD ( attention deficit hyperactive disorder)

Penelitian ini akan mengkaji persepsi para mahasiwa calon guru, tentang anak berkebutuhan khusus, yang mungkin akan menjadi siswa mereka pada saat mereka mengajar nanti. Arti dari persepsi itu sendiri, ada beberapa definisinya. Menurut Slameto (2015:103) persepsi merupakan prosedur masuknya pesan atau data ke otak manusia. Melalui persepsi seseorang secara kontinyu melakukan kontak dengan lingkungannya. Kontak ini terjadi melalui panca inderanya, yakni indera penciuman, perasa, peraba, pendengaran dan penglihatan. Selanjutnya Gibson dalam Pinaryo, (2014 : 55) memaparkan bahwa persepsi adalah prosedur kognitif yang dipakai seseorang untuk mengartikan dan menginterpretasikan dunia sekelilingnya. Dengan demikian persepsi juga membawa arti bagaimana seseorang berproses dalam memaknai lingkungannya. Penelitian dari Setyaningsih (2016:139-152) mengutip definisi Kotler mengenai persepsi sebagai tahapan seseorang untuk memilih, menyusun dan memaknai informasi dengan tujuan untuk mendapatkan deskripsi utuh yang berarti. Sehingga penelitiannya tentang persepsi bagi mahasiswa calon guru yang melakukan praktek lapangan tentang profesionalitas guru sekolah dasar, akan menolong mereka untuk memutuskan tindakan, tingkah laku, kegiatan serta target, sebagai standard yang harus dicapai untukmenjadi guru yang profesional. Berdasarkan kutipan dari beberapa penelitian tersebut, dapat disimpulkan persepsi merupakan merupakan suatu kecenderungan dalam melihat peristiwa atau kegiatan yang sama dengan cara yang berbeda-beda. Oleh karena itu, untuk peristiwa yang sama, cara melihat tiap orangnya bisa berbeda. Dengan demikian, kaitan antara persepsi mahasiswa calon guru, terhadap anak berkebutuhan khusus, akan sangat menentukan kesiapannya untuk mengajar mereka, suatu kelak nanti ketika mereka sudah menjalankan profesinya sebagai guru, khususnya di sekolah inklusi.

Mengajar di satu sisi adalah ilmu pengetahuan dalam hal mendidik (pedagogi) dan di satu sisi adalah seni. Mengajar membutuhkan pengetahuan agar strategi yang digunakan tepat dengan perkembangan belajar anak sehingga tujuan pembelajaran akan tercapai, Tung (2015:11). Dengan adanya peraturan pemerintah tentang sekolah inklusi, yang mewajibkan semua sekolah untuk menerima siswa didik, termasuk di dalamnya yang berkebutuhan khusus, maka seorang guru harus mempunyai kesiapan untuk melayani pendidikan anak anak berkebutuhan khusus juga. Ketrampilan atau kesiapan mengajar bukanlah bersifat keturunan, tetapi merupakan hasil dari pembelajaran dan pengalaman. Arti dari kata siap menurut KBBI adalah sudah disediakan (tinggal memakai atau menggunakan saja), jadi 
arti kata kesiapan bisa diartikan sebagai kondisi yang siap dipakai atau digunakan. Dalam konteks kesiapan mengajar sekolah inklusi bisa diartikan sebagai kondisi guru yang siap digunakan di sekolah inklusi. Sedangkan Slameto (2015:113), menyebutkan bahwa kesiapan adalah totalitas keadaan seseorang yang menyebabkan orang tersebut siap untuk memberikan jawaban secara khusus terhadap suatu keadaan tertentu.

Setiap individu adalah unik, berbeda satu dengan yang lain. Di antara sesama murid regular pun, berbeda dalam karakteristiknya (gaya belajar, kemapuan kognitif, kebutuhan, motivasi, dsb). Apalagi antara siswa regular dengan siswa yang mempunyai kebutuhan khusus. Bahkan siswa yang menyandang kebutuhan khusus pun, banyak jenisnya. Dengan demikian guru perlu cara mengajar yang sesuai dengan kebutuhan masing masing siswa yang ada di kelasnya. Guru harus menyadari bahwa mereka harus memodifikasi caranya mengajar, terutama untuk mengajar siswa berkebutuhan khusus, supaya mereka tetap mencapai kompetensi yang sama dengan teman teman regulernya. Cara guru mengajar harus cocok dan tepat sesuai dengan perbedaan setiap siswa. Dari pemaparan tersebut, jelas bahwa seorang guru harus mempunyai kesiapan untuk mengajar.

Kesiapan mengajar adalah merupakan salah satu kompetensi yang harus dimiliki seorang guru, demikian dinyatakan oleh Suharsimi Arikunto (2002: 54). Kesiapan perihal sikap, ketrampilan dan pengetahuan adalah hal-hal yang akan mendukung guru dalam mengajar anak berkebutuhan khusus. Hal ini disebabkan karena konsep inklusi mempunyai makna tidak adanya pemisahan ruang belajar antara anak berkebutuhan khusus dengan anak normal (Kurniadi dan Sunaryo, 2017). Seorang guru akan mempunyai kesiapan mengajar, apabila ia mempunyai kompetensi kompetensi yang harus dikuasai oleh seorang pendidik.

Permendiknas No 16 tahun 2007, pasal 20 ayat 1 tentang Standar Kualifikasi Akademik dan Kompetensi Guru, menyebutkan bahwa kompetensi yang harus dipunyai seorang guru ada 4, yaitu kompetensi pedagogik, kompetensi kepribadian, kompetensi sosial, dan kompetensi profesional. Kompetensi guru adalah harmonisasi antara pengembangan personal, penguasaan materi ajar, pemahaman mendalam terhadap karakteristik siswa, dan proefesionalise. Sehingga jelas terlihat bahwa menguasai karakteristik peserta didik merupakan salah satu faktor yang menentukan kesiapan mengajar seorang guru. Menurut Djiwandono (2008: 17-23), ada empat bidang kompetensi yang harus dimiliki seorang guru. Yang pertama adalah memiliki pengetahuan tentang teori belajar dan tingkah laku manusia. Kedua, menunjukkan sikap dalam membantu siswa belajar dan memupuk hubungan dengan manusia lain secara tulus. Ketiga, menguasai mata pelajaran yang diajarkan. Keempat, mengontrol ketrampilan tehnik mengajar sehungga memudahkan siswa belajar. Dapat dikatakan bahwa persiapannya untuk mengajar di sekolah inklusi, bukan hanya dalam hal kompetensi pedagogik saja, seperti yg dikemukakan oleh Muspiroh (2016: 4), bahwa guru yang mempunyai kompetensi sosial yang baik, akan mempunyai sikap tenggang rasa yang tinggi, mempunyai kecakapan verbal maupun non verbal yang tinggi, dalam menerima ataupun memberikan pesan. Kecakapan kecakapan tersebut, tentu saja akan mendukung untuk seorang guru mengenali kebutuhan anak-anak special needs.

\section{METODE PENELITIAN}

Populasi penelitian adalah mahasiswa Teacher College yang mendapatkan mata kuliah Pendidikan Luar Biasa/ Teaching Childen With Diverse Ability di semester ganjil 2019, sejumlah 2 kelas yang terdiri dari 4 prodi, dengan total mahasiswa 82 orang. Dari populasi tersebut, dipilih 1 kelas yang terdiri dari 2 prodi, sebagai sampel, dengan jumlah mahasiswa 40 orang. Penelitian dimulai dari Agustus sampai November 2019.

Jenis dari penelitian ini adalah kualitatif yang definisinya adalah jenis penelitian yang temuan temuannya tidak diperoleh melalui prosedur statistik atau bentuk hitungan lainnya (Afrizal, 2016-: 12). Tehnik pengumpulan data dilakukan melalui wawancara, angket dan dokumentasi.

Analisa data yang digunakan adalah analisa Model Miles dan Huberman (Sugiyono, 2015: 337) Analisa dilakukan pada saat pengumpulan data berlangsung dan setelah selesai pengumpulan dalam periode tertentu. Aktifitas dalam analisa data adalah reduksi data, display/ penyajian data, dan penarikan kesimpulan. Pengecekan keabsahan data untuk uji validitas dan reliabilitas menggunakan tehnik triangulasi. Triangulasi untuk pengujian kredibilitas artinya adalah pengecekan data dari berbagai sumber dengan berbagai cara dan berbagai waktu, sehingga akan didapati triangulasi sumber, triangulasi tehnik pengumpulan data, dan juga waktu. Triangulasi dilakukan dengan melakukan 
pengecekan data kepada sumber yang sama dengan tehnik yang berbeda, yaitu dengan memakai angket, wawancara dan dokumentasi.

\section{HASIL PENELITIAN DAN PEMBAHASAN}

Implementasi peraturan pemerintah tentang Sistem pendidikan Nasional yang sudah dibahas di pendahuluan, adalah seluruh sekolah mempunyai kewajiban untuk memberikan kesempatan kepada anak berkebutuhan khusus untuk mendapatkan akses pendidikan. Kekhususan yang dimiliki oleh anak, seharusnya tidak menghalangi hak nya untuk mendapatkan pendidikan seperti anak anak normal lainnya, Dengan demikian persepsi calon guru ataupun guru terhadap anak berkebutuhan khusus, sangat menentukan kesiapannya untuk mengajar anak anak spesial, dalam hal ini khususnya di sekolah inklusi.

Berdasarkan hasil angket dan wawancara, persepsi mahasiswa calon guru, tentang apakah anak berkebutuhan khusus bisa mendapatkan akses pendidikan dan akan berhasil di sekolah inklusi, semua partisipan menjawab bisa. Sedangkan argumentasinya, dideskripsikan berdasarkan tiga kategori yaitu: 1) Pendidikan merupakan hak dasar setiap orang; 2) Sekolah inklusi merupakan pengkombinasian antara sekolah umum dengan sekolah luar biasa; dan 3) Penyesuaian yang dilakukan dengan PPI (Program Pengembangan Individu).

Pada kategori pendidikan merupakan hak dasar setiap orang, beberapa kutipan pendapat responden, menjelaskan tentang hak antara lain adalah: "Siswa berkebutuhan khusus bisa masuk sekolah inklusi, karena pada dasarnya semua anak harus mendapat pendidikan yang sama, karena mereka juga punya hak akan Pendidikan seperti anak anak lainnya." "Pendidikan inklusi berupaya untuk menjamin kesetaraan anak anak berkebutuhan khusus dengan anak anak normal, baik secara afektif,kognitif, dan sosial dengan upaya penyesuaian dari sisi kurikulum, metode mengajar, penilaian, dan lain lain". "Pendidikan inklusi dibuat dengan tujuan menyatukan atau menggabungkan pendidikan regular dengan Pendidikan khusus dalam satu sistem lembaga Pendidikan. Dengan adanya pendidikan inklusi, anak anak berkebutuhan khusus dapat merasakan bagaimana rasanya bersekolah di sekolah umum dan di tengah-tengah anak normal lainnya". Undang-Undang Nomor 20 pasal 5 ayat 1, menegaskan bahwa setiap warga negara mempunyai hak yang sama untuk memperoleh pendidikan. Salah satu bentuk kesamaan dan wujud pendidikan yang tidak membedakan antara anak anak pada umumnya dengan anak anak berkebutuhan khusus adalah pendidikan inklusi. Hasil penelitian ini sejalan dengan pemikiran yang tertuang dalam beberapa artikel, di antara nya adalah Sunanto dan Hidayat (2016: 47), sehingga setiap orang harus dapat mengecap pendidikan tanpa membeda bedakan kondisinya. Demikian juga penelian dari Murniati dan Anastasia (2016 : 9-18), tujuan dari Pendidikan inklusif adalah untuk memberikan peluang dan keleluasaan bagi siswa berkebutuhan khusus untuk mendapatkan Pendidikan yang bermutu dan bermakna, selain itu juga mewujudkan konsep Pendidikan yang menjunjung nilai kemajemukan dan tidak diskriminatif.

Pada kategori sekolah inklusi merupakan pengkombinasian antara sekolah umum dengan sekolah luar biasa, diperoleh kutipan dari beberapa hasil wawancara berikut: "Sekolah inklusi didesain dengan mengkombinasikan sekolah umum dan sekolah luar biasa, dimana dalam keragaman anak berkebutuhan khusus akan belajar bersama dengan anak-anak regular lainnya." "Siswa berkebutuhan khusus pada prinsipnya memiliki kebutuhan yang berbeda dengan siswa lainnya, atau dengan pengertian lain mereka membutuhkan pendidikan khusus untuk menunjang kebutuhannya.Apabila mereka tidak ditempatkan di sekolah yang tepat, maka mereka akan cukup kesulitan baik dalam akademik maupun non akademik. Sekolah inklusi merupakan sekolah pengkombinasian antara sekolah umum dengan sekolah luar biasa, dimana keberagaman anak berkebutuhan khusus akan belajar bersama denngan anak normal lainnya dalam sebuah kelas, dengan sarana, prasarana, metode mengajar, dan kurikulum yang disesuaikan dengan kebutuhan anak siswa berkebutuhan khusus tersebut." "Ya, karena sekolah inklusi merupakan sekolah yang didesain untuk ABK dan siswa normal. Sekolah inklusi menerima ABK yang memiliki kemampuan kognisi yang baik (SLB A,C,D, dan E). Selama siswa yang berkebutuhan khusus tidak terkendala masalah akademik atau kognitif, dan bisa mengikuti instruksi dan aturan sekolah maka bisa dibimbing di sekolah inklusi. Hal ini juga membantu siswa untuk berinteraksi secara sosial dengan siswa normal atau dengan kata lain bisa terjun ke dunia di luar zona nyamannya'. Beberapa kutipan wawancara hasil penelitian ini, didukung hasil penelitian dari Sunanto dan Hidayat (2016 : 47-64) dalam artikelnyaDesain Pembelajaran Anak Berkebutuhan Khusus dalam Kelas Inklusif mengungkapkan bahwa pendidikan inklusif melakukan pendekatan yang merombak sistem pendidikan, 
dengan tujuan semua peserta didik yang mempunyai banyak keragaman, semuanya dapat di akomodasi. Hal ini dilakukan dengan maksud agar siswa maupun guru sama-sama merasa nyaman dengan adanya keragaman ini dan menyikapinya secara positif sebagai sebuah hal yang memperkaya, dan bukan sebaliknya memandang sebagai sebuah problem yang menjadi masalah. Penelitian serupa oleh Kadir (2015:2-22) Tidak semua siswa disabilitas bisa mendapatkan akses pendidikan secara leluasa di SLB, oleh karena itu pemerintah mengusahakan pendidikan di sekolah yang paling dekat dengan tempat tinggal para siswa ini, yang didesain secara khusus, inilah sekolah inklusi.

Pada kategori penyesuaian yang dilakukan dengan PPI (Program Pengembangan Individu), seorang guru kelas seharusnya membuat PPI bagi setiap anak berkebutuhan khusus yang ada di kelasnya. PPI adalah rencana pembelajaran yang dikembangkan untuk seorang anak berkebutuhan khusus, yang merupakan sebuah hasil diskusi kesepakatan yang dilakukan oleh guru kelas, orang tua anak yang bersangkutan, kepala sekolah, wakil kepala sekolah, guru bimbingan dan konseling, serta apabila ada psikolog yang menangani anak berkebutuhan khusus tersebut. Kutipan responden yang mengetengahkan tentang PPI sebagai berikut: "Siswa dengan kebutuhan khusus bisa sukses dalam studinya dengan bersekolah di sekolah untuk siswa normal, apabila dilakukan beberapa penyesuaian, salah satunya dengan dibuatnya PPI (Program Pengembangan Individu).PPI yang tepat seharusnya berisi tentang masalah yang dihadapi oleh siswa (berkaitan dengan kebutuhan khususnya) dan strategi mengajar yang ditunjang oleh sarana prasarana untuk mengatasi kebutuhan khususnya tersebut." "Salah satu faktor yang merupakan kunci keberhasilan siswa dengan kebutuhan khusus bersekolah di sekolah inklusi adalah adanya PPI (Program Pengembangan Individu) yang dibuat masing masing sesuai dengan kekhususan setiap siswa. PPI dikembangkan berdasarkan diskusi bersama antara orang-orang terdekat siswa yang bersangkutan dengan pihak sekolah serta konselor, baik dari sekolah maupun yang dirujuk oleh keluarga siswa. PPI ini tentu saja akan memaksimalkan setiap proses penyusunan serta pembelajaran, sehingga dampaknya siswa akan berkembang dengan maksimal meskipun mempunyai kekhususan'. "Dengan penggunaan stategi dan PPI yang tepat, anak berkebutuhan khusus bisa berkembang dengan maksimal di sekolah inklusi. Walaupun tidak secepat anak normal pada umumnya, namun dengan strategi dan PPI yang diatur dengan melihat kebutuhan mendasar anak berkebutuhan khusus tersebut, maka perkembangannya akan berjalan dengan baik." "Sekolah inklusi akan melakukan penyesuaian pembelajaran dengan mengembangkan PPI. PPI berfungsi untuk mengenali kondisi anak dan memantau perkembangannya secara kognitif, afektif dan psikomotorik. Tidak hanya itu, dalam pembuatan PPI sekolah juga melibatkan beberapa pihak seperti orang tua dan konselor khusus untuk menangani kondisi anak, terutama dalam lingkup sekolah. Dengan demikian anak berkebutuhan khusus dapat diberikan latihan dan pembelajaran khusus sesuai kebutuhannya dan ia dapat berkembang maksimal seperti anak anak normal." "Dengan adanya PPI, guru, orangtua, dan bagian sekolah dapat dipermudah untuk memahami kebutuhan setiap ABK, baik kebutuhan dalam Pendidikan seperti sarana dan prasarana yang dibutuhkan siswa di sekolah maupun relasi bersama teman, guru, dan orangtuanya. Sehingga dapat sangat membantu dalam proses perkembangan diri siswa." Selaras dengan kutipan wawancara tersebut adalah penelitian dari Frisia (2017:15), variasi dan perluasan kurikulum adalah sesuatu hal yang harus dilakukan dalam pendidikan inklusi, sehingga anak berkebutuhan khusus akan dapat megalami pembelajaran yang bermakna, seperti anak normal lainnya. PPI adalah pengejawantahan dari modikasi kurikulum. Hasil penelitian memperlihatkan bahwa PPI mempunyai kapasitas yang signifikan dalam mengoptimalkan potensi siswa berkebutuhan khusus. Begitu juga pemaparan hasil penelitian oleh Koeriah (2017 :48-49) PPI adalah media pendidikan yang digunakan untuk menolong anak berkebutuhan khusus beradapatasi di lingkungan sekolah inklusi. Siswa yang mempunyai kebutuhan khusus pastinya menghadapi tantangan yang cukup besar, sehingga perlu bantuan yang sesuai dengan kebutuhannya dan kapabilitasnya. PPI disusun secara individual, berdasarkan diskusi bersama antara sekolah, orang tua , dan anak didik berkebutuhan khusus.

Tujuan kedua dari penelitian ini adalah tentang kesiapan dari mahasiswa guru Universitas Pelita Harapan untuk mengajar disekolah inklusi. Hasil dari wawancara, semua responden menyatakan kesiapannya untuk mengajar di sekolah inklusi. Peneliti menyusun beberapa alasan yang mendasari kesiapan para mahasiswa guru tersebut adalah : 1) Setiap anak yang ingin belajar mempunyai hak dan kewajiban yang sama, sebagai pengajar tidak boleh membeda-bedakan anak berkebutuhan khusus ataupun normal. Pendapat ini sesuai dengan penelitian dari Cahyaningrum (2012:1-10), bahwa rata-rata kesiapan pendidik tingkat dasar dan menengah Alam Ar-Ridho mengajar peserta didik berkebutuhan khusus terbilang tinggi, salah satu faktornya karena pengajar mempunyai nilai nilai yang positif 
terhadap anak berkebutuhan khusus, diantaranya adalah dengan tidak memperlakukan berbeda, diberikan kesempatan yang sama. 2.)Mata kuliah Pendidikan Luar Biasa yang sudah diikuti membukakan pengetahuan dan wawasan mahasiswa guru tentang jenis jenis kebutuhan khusus, apa saja ciri cirinya, bagaimana mendeteksinya di dalam kelas, dan bagaimana strategi mengajar anak anak spesial tersebut.Dengan demikian, akan menjadi bekal dalam mengajar anak spesial, yang akan berpengaruh juga terhadap sikap dan penerimaan guru terhadap anak berkebutuhan khusus.Hasil penelitian Salamah (2016:11-12) menegaskan pendapat ini, yakni pendidik tingkat dasar di Sekolah Dasar N Pojok, kurang siap dalam pengajaran untuk anak anak berkebutuhan khusus, disebabkan kekurang siapan guru antara lain adalah kurangnya pengetahuan dan pemahaman bagaimana mengajar anak berkebutuhan khusus, kurangnya sambutan guru terhadap hadirnya anak anak spesial tersebut di kelasnya, serta faktor internal berupa sikap negatif guru terhadap anak berkebutuhan khusus.

Selanjutnya Kurniadi dan Sunaryo (2017:27) memaparkan hasil penelitiannya, mahasiwa program PGSD belum mempunyai kesiapan dalam melayani pendidikan anak anak berkebutuhan khusus di SD. Ketidaksiapan ini disebabkan karena, mahasiswa S1 PGSD tidak mendapatkan pembekalan di sebagai persiapan mengajar siswa yang mempunyai kebutuhan khusus. Di dalam kurikulum program S1 PGSD baru diberikan pengantar tentang konsep pokok pendidikan inklusi. 3). Responden siap mengajar di sekolah inklusi, karena selain kesiapan dari segi pedagogi pengajar, sekolah inklusi juga mengakomodasi kebutuhan siswa dalam hal sarana prasarana, kurikulum, metode, dan jenis asesmen yang terbaik untuk anak special need. Hal ini yang mendorong mereka untuk memiliki passion mengajar di sekolah inklusi." Kutipan wawancara tersebut, menunjukkan bahwa meskipun siswa regular dan siswa berkebutuhan khusus belajar bersama sama dalam satu kelas, tetapi pembelajaran tetap harus bermakna, sehingga sekolah inklusi seharusnya melakukan penyesuaian dalam beberapa hal yang disebut di atas. Pendapat ini sangat didukung oleh penelitian dari Murniati dan Ansatasia (2016:9-18), yang memaparkan strategi, konsep dan implementasi pendidikan inklusi. Konsep pendidikan inklusi salah satunya adalah sistem pelaksanaan pendidikan harus dapat memenuhi kebutuhan semua siswa, termasuk siswa berkebutuhan khusus. Implementasi mencakup penyesuaian kurikulum, assessment, penilaian hasil belajar dan sistem kelulusan. Sedangkan untuk strategi mencakup penyesuaian atau modifikasi dan kemudahan atau akomodasi bagi siswa berkebiutuhan khusus, sehingga dapat memaksimalkan semua potensi mereka dalam mengikuti pembelajaran. Hal tersebut misalnya pemenuhan sarana prasara yang dibutuhkan, menggunakan berbagai macam metode pengajaran, dan lain sebagainya.

Selaras dengan penelitian dari Kadir, (2015 : 1-22) Sekolah inklusi dirancang sesuai standar sekolah reguler, namun tetap melayani siswa berkebutuhan khusus dengan penyesuaian penyesuaian yang diperlukan, seperti halnya kurikulum, metode, strategi, sarana prasarana, maupun asesmen. Sependapat dengan hasil penelitian Herawati (2010:1-11) berbagai penyesuaian dalam rangka penyelenggaraan pendidikan inklusi harus dilakukan, baik dari segi sistem pembelajaran, sarana prasarana, maupun kurikulum. Sekolah harus mengakomodasi kebutuhan peserat didik dan bukan sebaliknya. Demikian pula penelitian Mareza (2017:35-38) dalam artikelnya di jurnal Scholaria yang menyoroti strategi Intervensi Umum bagi anak berkebutuhan khusus melalui pendidikan seni budaya, dalam kesimpulannya menyatakan bahwa penyampaian kurikulum melalui strategi intervensi dengan memodifikasi proses pembelajaran secara akademis dan penghargaan karya seni. Selanjutnya Sunanto dan Hidayat (2016 : 47-64) dalam artikelnya Desain Pembelajaran Anak Berkebutuhan Khusus dalam Kelas Inklusif mengungkapkan bahwa pendidikan inklusif melakukan pendekatan yang merombak sistem pendidikan, dengan tujuan semua peserta didik yang mempunyai banyak keragaman, semuanya dapat di akomodasi. Hal ini dilakukan dengan maksud agar siswa maupun guru sama-sama merasa nyaman dengan adanya keragaman ini dan menyikapinya secara positif sebagai sebuah hal yang memperkaya, dan bukan sebaliknya memandang sebagai sebuah problem yang menjadi masalah..

\section{SIMPULAN DAN SARAN}

Dari pembahasan yang dipaparkan di atas, dapat ditarik kesimpulan bahwa mahasiswa calon guru mempunyai persepsi bahwa anak berkebutuhan khusus bisa dan akan berhasil jika bersekolah di sekolah inklusi. Argumentasi yang mendasari persepsi tersebut ada tiga hal yaitu kesamaan hak untuk mendapatkan pendidikan bagi setiap orang, sekolah inklusi merupakan pengkombinasian antara sekolah umum dengan sekolah luar biasa, dan terakhir adalah adanya penyesuaian pembelajaran bagi 
tiap anak berkebutuhan khusus dalam bentuk PPI (Program Pengembangan Individu). Sedangkan untuk kesiapan mengajar, semua responden menyatakan kesiapannya untuk mengajar di sekolah inklusi. Pernyataan kesiapan ini sangat penting, mengingat bahwa guru adalah salah satu determinan keberhasilan pendidikan inklusi. Oleh sebab itu faktor kesiapan para calon guru ini menjadi sangat menentukan, mengingat dalam setting pendidikan inklusi, setiap guru harus siap mengajar baik murid yang normal ataupun murid yang berkebutuhan khusus. Alasan yang mendasari kesiapan mereka adalah bahwa pengajar tidak boleh membeda-bedakan anak setiap siswanya apapun kondisinya, pembekalan mata kuliah pendidikan luar biasa yang sudah diikuti, sekolah inklusi mengakomodasi kebutuhan siswa dalam hal sarana prasarana, kurikulum, metode, dan jenis asesmen yang terbaik untuk anak special need

Dari kajian ini juga terlihat pentingnya untuk mahasiswa calon guru dipersiapkan untuk mengajar anak-anak berkebutuhan khusus di sekolah inklusi, pada saat masa studinya, melalui mata kuliah Teaching Chidren With Diverse Ability atau pendidikan luar biasa. Kompetensi yang diharapkan akan terpenuhi dari mata kuliah ini antara lain adalah mahasiswa mampu mengidentifikasi anak berkebutuhan khusus berdasarkan karakternya, serta mampu menganalisis masalah anak berkebutuhan khusus dengan strategi pembelajaran yang sesuai. Disarankan untuk membekali setiap mahasiswa calon guru di setiap program studi dengan mata kuliah pendidikan luar biasa, sehingga akan membantu mempersiapkan mereka untuk mengajar di sekolah inklusi. Hal ini pada gilirannya akan menjadi solusi dari salah satu masalah pendidikan di Indonesia, yaitu kendala pelaksanaan pendidikan inklusi, dari sisi faktor kesiapan pendidik atau guru. Terkait penelitian lanjutan, salah satu hal penting yang dibahas adalah PPI. Mahasiswa calon guru akan melaksanakan praktek mengajar atau PPL sebelum menjadi guru. Pada saat praktek lapangan, bisa mengembangkan PPI dan meneliti keefektifitasan PPI untuk menolong memaksimalkan pembelajaran anak berkebutuhan khusus di sekolah inklusi.

\section{DAFTAR PUSTAKA}

Afrizal. 2016. Metode Penelitian Kualitatif. Depok: Raja Grafindo Perkasa

Amka. 2019. Pendidikan Inklusif Bagi Siswa Berkebutuhan Khusus di Kalimantan Selatan. Jurnal Pendidikan dan Kebudayaan. 4, (1). Retrieved from https://jurnaldikbud.kemdikbud.go.id /index.php/ jpnk/article/view/1234

Anggriana,T.M.\& Trisnani,R.P. 2016. Kompetensi Guru Pendamping Siswa ABK di Sekolah Dasar, dalam Jurnal Konseling GUSJIGANG. 2 (2). Retrieved from https://jurnal.umk.ac.id/ index.php/gusjigang/article/view/702

Bennet, C.I. 2001 Genres of Research in Multicultural Education. Review of Educational Research 71(2):171- 217. Retrieved from https://journals.sagepub.com/doi/abs/ 10.3102/00346543071 002171

Cahya,L.S. 2017. Adakah ABK di Kelasku, Bagaimana Guru Kelas Mengenali ABK di Sekolah Umum. Jakarta : Familia Pustaka Keluarga

Cahyaningrum,R.K. 2012. Tinjauan Psikologis Kesiapan Guru Dalam Menangani Peserta Didik Berkebutuhan Khusus Pada Program Inklusi (studi deskriptif di SD dan SMP sekolah alam arridho) dalam Educational Psychology Journal. 1 (1). Retrieved from http://journal.unnes.ac.id/sju/index.php/epj

Chamidah,A.N. 2014. Mengenal Anak Berkebutuhan Khusus, dalam Pelatihan Layanan Komprehensif Bagi Anak Berkebutuhan Khusus di Sekolah Inklusif . Retrieved from http://staffnew.uny.ac.id/upload/132326899/pengabdian/mengenal-abk.pdf

Djiwandono \& Wuryani, 2008. Psikologi Pendidikan. Jakarta: PT Grasindo.

Farisia,H. 2017 .Strategi Optimalisasi Kemampuan Belajar Anak Berkebutuhan Khusus (abk) Melalui Program Pembelajaran Individual (PPI) dalam SELLING. Jurnal Program Studi PGRA. 3 (2) Retrieved from http://digilib.uinsby.ac.id/28590/1/116-Article\%20Text-284-2-1020171124.pdf 
Persepsi dan Kesiapan Mengajar Mahasiswa Guru Terhadap Anak Berkebutuhan Khusus dalam

Konteks Sekolah Inklusi (M.Kusuma Wardhani)

Kadir,A. 2015. Penyelenggaraan Sekolah Inklusi Di Indonesia,dalam Jurnal Pendidikan Agama Islam 03 (01), 1-22. Retrieved from https://media.neliti.com/media/publications/117580-IDpenyelenggaraan-sekolah-inklusi-di-indon.pdf

Khoeriah,N.D. 2017 INDIVIDUALIZED EDUCATIONAL PROGRAM Dalam Implementasi Pendidikan Inklusif, dalam Inclusive: Journal of Special Education. III (01). Retrieved from ojs.uninus.ac.id > index.php > Inclusi > article > view.

Murniati,E. \& Anastasia, N.Z., 2016 Pendidikan Inklusif di Tingkat Sekolah Dasar:Konsep, Implementasi, dan Strategi. Jurnal J D P, 9 (1). Retrieved from http://repository.uki.ac.id/ 786/1/Erni\%20Muniarti\%202016.pdf

Halim, J.P., Mohamad,E, 2018 Studi Kasus Implementasi Layanan Pendidikan Inklusif di Kota Madiun. Jurnal ortopedagogia. 4 (1). Retrieved from https://journal2.um.ac.id/index.php/jo/ article/view/4406

Hasnul,N., 2011. Sikap Mahasiswa Terhadap Pelaksanaan Pendidikan Inklusi, dalam Jurnal Perspektif Ilmu Pendidikan . 24 (XV). Retrieved from http://journal.unj.ac.id/unj/index.php/pip/article/ view/7412

Herawati,N.I., 2010. Pendidikan Inklusi, dalam Jurnal Eduhumaniora Vol 2 No 1 Retrieved from https://www.neliti.com/id/publication /240795/ pendidikan-inklusif

Juang, S.\& Hidayat, 2016. Desain Pembelajaran Anak Berkebutuhan Khusus dalam Kelas Inklusif dalam Jurnal JASSI_ANAKKU Jurnal Asesmen dan Intervensi Anak Berkebutuhan Khusus. 17 (1). Retrieved from https://ejournal.upi.edu/index.php/jassi/article/view/5738/3900

Knight, G.R, 2009. Filsafat dan Pendidikan, Universitas Pelita Harapan Press Tangerang

Kurniadi \& ,Sunaryo, 2017. Kesiapan Mahasiswa Calon Guru Sekolah Dasar Dalam Melayani Anak Berkebutuhan Khusus dalam Jurnal JASSI ANAKKU. 18 (2). Retrieved from https://ejournal .upi. edu/ index.php/jassi/article/view/9690

Mareza,L.,2017. Pendidikan Seni Budaya dan Prakarya (SBdP) Sebagai Strategi Intervensi Umum bagi Anak Berkebutuhan Khusus. Jurnal SCHOLARIA. 7 (1). Retrieved from https://ejournal.uksw.edu/scholaria/article/view/711

Mudjito, dkk. 2012. Pendidikan Inklusif : Tuntunan Guru, Siswa dan Orang Tua Anak Berkebutuhan Khusus dan Layanan Khusus. Jakarta: Baduose Media.

Mumpuniarti M.\& Lestari,P.H.K. 2018. Kesiapan Guru Sekolah Reguler Untuk Implentasi Pendidikan Inklusif, dalam JPK (Jurnal Pendidikan Khusus),14(2), 2018 Retrieved from https://journal.uny.ac.id/index.php/jpk/article/view/25167

Murniarti, E., \& Anastasia, N. Z.,2016. Pendidikan Inklusif Di Tingkat Sekolah Dasar, dalam Jurnal Dinamika Pendidikan, 9(1), 9. Retrieved from https://doi.org/10.33541/jdp.v9i1.134

Muspiroh,N., 2016. Peran Kompetensi Sosial Guru Dalam Menciptakan Efektifitas Pembelajaran, dalam journal of Social Science 28, (2) Retrieved from https://syekhnurjati.ac.id/jurnal/index.php/edueksos/article/view/655

Pinaryo,2014. Persepsi Mahasiswa Universitas Muhammadiyah Ponorogo Terhadap Program Kewirausahaan Mahasiswa, dalam Jurnal Aristo. 2 (2), 55. Retrieved from http://journal.umpo.ac.id/index.php/aristo/article/view/22/276

Salamah,U, 2015.Kesiapan Guru Kelas Dalam Menangani Anak Berkebutuhan Khusus di SD N Pojok Kabupaten Sleman dalam Skrisi Program Studi Pendidikan Guru Sekolah Dasar jurusan Pendidikan Pra Sekolah dan SD Fakultas Ilmu Pendidikan Universitas Negeri Yogyakarta Retrieved from http://journal.student.uny.ac.id > article

Saleh, Filawati, 2019. Efektifitas Penerapan Model Pembelajaran Kooperatif Tipe Students Team Achievement Division Dalam Meningkatkan Aktivitas Dan Hasil Belajar Kognitif Siswa, 
dalam Edubiotik : Jurnal Pendidikan, Biologi dan Terapan . 4 (02). Retrieved from http://ejurnal.budiutomomalang.ac.id/index.php/edubiotik/article/view/449/360

Salinan Lampiran Peraturan Menteri Pendidikan Nasional Nomor 16 Tahun 2007 TanggaL 4 MEI 2007, Standar Kualifikasi Akademik dan Kompetensi Guru. vervalsp.data.kemdikbud.go.id

Setyaningtyas, E.W.2016. Persepsi Mahasiswa PPL 1 dan 3 PGSD BIPE UKSW Mengenai Profesi Guru SD Yang Profesional Dan Pengajaran Literasi, dalam Jurnal SCHOLARIA. 6 (2) Retrieved from https://ejournal.uksw.edu/scholaria/article/view/235/213

Slameto, 2015. Belajar dan Faktor Faktor Yang Mempengaruhinya. Pt Rineka Cipta, Jakarta.

Smith, D.,2006. Sekolah Ramah Untuk Semua. Bandung: Penerbit Nuansa.

Sunanto,J \& Hidayat, Desain Pembalajaran Anak Berkebutuhan Khusus di Kelas. Jurnal Asesmen dan Intervesi Anak Berkebutuhan Khusus. 17(1). Retrieved from https://ejournal.upi.edu/index.php/jassi/article/view/5738/3900

Sugiarmin,M.,2003. Peserta Didik Berkebutuhan Khusus Dalam Perspektif Pendidikan Inklusif, Retrieved from http://file.upi.edu/Direktori/FIP/JUR._PEND._LUAR_BIASA/ 19540527 1987031 -MOHAMAD_SUGIARMIN/artikel_untuk_dies_natalis.pdf.

Sugiyono, 2016. Metode Penelitian Pendidikan. Bandung: PT Alfabeta.

Tarnoto,N.,2016. Permasalahan-Permasalahan Yang Dihadapi Sekolah Penyelenggara Pendidikan Inklusi Pada Tingkat SD, dalam Jurnal HUMANITAS. 13 (1). Retrieved from https://www.ejurnal.com/2016/05/

Tung, K.Y.,2015. Pembelajaran dan Perkembangan Belajar. Jakarta: Penerbit Indeks.

UU Sisdiknas no 20 th 2003 tentang Sistem Pendidikan Nasional pasal 32

Wuryandani,W., Fathurrohman, Senen,A., Haryani, 2018. Implementasi Pemenuhan Hak Anak Melalui Sekolah Ramah Anak. Jurnal Civics: Media Kajian Kewarganegaraan 15 (1), 86-94. Retrieved from https://journal.uny.ac.id/index.php/civics/article/view/19789/pdf 